\title{
Effect of Cigarette Circumference on Weight Loss during Puffs and Total Delivery of Tar and Nicotine*
}

\author{
by T. Yamamoto, U. Anzai and T. Okada
}

Central Research Institute, The Japan Tobacco and Salt Public Corporation, Yokohama, Japan

\section{SUMMARY}

Using cigarettes of different circumference but a constant packing density, the weight loss during a puff, $W_{p}$, and the total deliveries of tar and nicotine were measured. The results obtained can be summarized as follows: the puff count, $n$, and the weight loss during a puff, $\mathbb{W}_{p}$, were nearly proportional to the radius of the cigarette. The total deliveries of tar and nicotine were closely proportional to the weight loss during puffs. Based on these results the following equations were derived:

for tar:

$$
T_{s}=K_{t}(W / L) e^{-\mu_{\mathrm{r}} l_{\mathrm{r}}} e^{-\mu_{\mathrm{f}} \mathrm{f}_{\mathrm{f}}}
$$

for nicotine:

$$
N_{s}=K_{n}(W / L)\left(n_{s} / 100\right) e^{-\mu_{s} l_{t}} e^{-\mu_{f} l_{f}},
$$

where

$\mathrm{T}_{s}=$ amount of tar in mainstream smoke,

$\mathrm{N}_{\mathrm{s}}=$ amount of nicotine in mainstream smoke,

W = weight of tobacco column,

$\mathrm{L}=$ length of tobacco column,

$n_{s}$ = nicotine content (\%) based on actual weight,

$\mathrm{l}_{\mathrm{z}}$ - length of tobacco column butt,

$l_{f}$ - length of filter,

* Received: 29th November 1983 - accepted: 29th June 1984. $\mu_{\mathrm{r}}=$ filtration coefficient of tobacco column,

$\mu_{f}=$ filtration coefficient of filter,

$\mathrm{K}_{\mathrm{t}}$ = experimental constants depending on

$\left.K_{n}\right\}=$ blend type and others.

From these equations, the amount of tar and nicotine in mainstream smoke can easily be estimated.

\section{ZUSAMMENFASSUNG}

Unter Verwendung von Zigaretten gleicher Fülldichte und verschiedenen Umfangs wurde der Gewichtsverlust während eines Zuges, $\mathbb{W}_{p}$, und die Gesamtausbeute an Kondensat und Nicotin gemessen. Die Ergebnisse lassen sich wie folgt zusammenfassen: Es besteht eine fast proportionale Beziehung $z$ wischen der Zugzahl, $\mathrm{n}$, und dem Gewichtsverlust während eines Zuges, $W_{p}$, einerseits und dem Radius der Zigarette andererseits. Die Ausbeute an Kondensat und Nicotin ist dem Gewichtsverlust während der Züge nahezu proportional. Aus diesen Ergebnissen wurden folgende Gleichungen abgeleitet:

für Kondensat:

$$
T_{s}=K_{t}(W / L) e^{-\mu_{t} l_{t}} e^{-\mu_{f} l_{f}},
$$

für Nicotin:

$$
N_{s}=K_{n}(W / L)\left(n_{s} / 100\right) e^{-\mu_{t} l_{t}} e^{-\mu_{f} l_{f}},
$$


wobei:

$\mathrm{T}_{s}$ = Kondensatmenge im Hauptstromrauch,

$\mathrm{N},=$, Nicotinmenge im Hauptstromrauch,

W - Gewicht des Tabakstranges,

L - Länge des Tabakstranges,

$n_{s} \quad$ - Nicotingehalt (\%) auf der Basis des tatsächlichen Gewichtes,

$1_{\mathfrak{t}}$ - Länge des Tabakstrangstummels,

$1_{f}=$ Länge des Filters,

$\mu_{\tau} \quad=$ Filtrationskoeffizient des Tabakstranges,

$\mu_{f}=$ Filtrationskoeffizient des Filters,

$\mathrm{K}_{\mathrm{i}}$ experimentelle Konstanten in Abhängigkeit

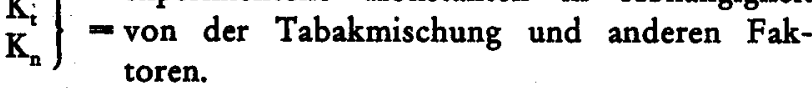

Mit Hilfe dieser Gleichungen ist die im Hauptstromrauch enthaltene Menge an Kondensat und Nicotin leicht $\mathrm{zu}$ bestimmen.

\section{RÉSUMÉ}

La perte de poids se produisant au cours d'une bouffée, $W_{p}$, et le rendement total en condensat et en nicotine ont été mesurés sur des cigarettes de différentes circonférences mais de densité de remplissage constante. Les résultats peuvent être résumés comme suit: il existe à peu de choses près une relation de proportionnalité entre le nombre $n$ de bouffées et la perte de poids $W_{p}$ observée lors d'une bouffée d'une part, et le rayon de la cigarette d'autre part. Le rendement en condensat et en nicotine est pratiquement proportionnel a la perte de poids pendant les bouffées. Ces résultats ont conduit aux expressions suivantes:

pour le condensat:

$$
T_{s}=K_{t}(W / L) e^{-\mu_{t} l_{t}} e^{-\mu_{f} l_{f}}
$$

pour la nicotine:

$$
N_{s}=K_{n}(W / L)\left(n_{s} / 100\right) e^{-\mu_{t} l_{t}} e^{-\mu_{f} l_{f}},
$$

dans lesquelles:

$\mathrm{T}_{s} \quad$ - quantité de condensat dans la fumée du courant principal,

$\mathrm{N}_{s}$ - quantité de nicotine dans la fumée du courant principal,

W = poids du boudin de tabac,

$\mathrm{L}=$ longueur du boudin de tabac,

$\mathrm{n}_{\mathrm{s}} \quad$ = teneur en nicotine (\%) sur la base du poids réel,

$l_{\mathfrak{t}} \quad$ - longueur du mégot,

$\mathrm{l}_{\mathrm{f}}=$ longueur du filtre,

$\mu_{r} \quad=$ coefficient de filtration du boudin de tabac,

$\mu_{\mathrm{f}}=$ coefficient de filtration du filtre,

$K$ constantes expérimentales dépendant du $\left.\begin{array}{l}\mathrm{K}_{\mathrm{t}} \\ \mathrm{K}_{\mathrm{n}}\end{array}\right\}=\begin{aligned} & \text { mélange de tabacs utilisé ainsi que d'autres } \\ & \text { facteurs. }\end{aligned}$

Les quantités respectives de condensat et de nicotine contenues dans la fumée du courant principal peuvent être déterminées facilement au moyen de ces expressions.

\section{INTRODUCTION}

Cigarette circumference is an important physical characteristic of cigarette design. A change in the circumference has an influence on the amount of smoke components in the mainstream smoke through two contradictory factors. One is smoke generation during puffs and the other is the behaviour of smoke after generation, i.e. the retention of particulate matter by the butt and the diffusion of gas components through the cigarette paper. As for the former, a reduction in the amount of smoke generated is expected with decreasing circumference, because both the puff count (1) and the weight loss during a puff (2) decrease. However, retention by the butt and diffusion through the cigarette paper are expected to decrease with decreasing circumference due to an increase in the velocity of the air passing through the cigarette.

\begin{tabular}{|c|c|c|c|c|}
\hline & $\begin{array}{l}\text { Circumference } \\
\text { (mm) }\end{array}$ & $\begin{array}{l}\text { Weight } \\
\text { (g) }\end{array}$ & $\begin{array}{l}\text { Pressure drop } \\
\text { (mm w.g.) }\end{array}$ & $\begin{array}{l}\text { Packing density } \\
\qquad\left(\mathrm{g} / \mathrm{cm}^{3}\right)\end{array}$ \\
\hline \multirow[t]{4}{*}{ Virginia blend type } & 21.1 & $0.682 \pm 0.01$ & $79.9 \pm 3$ & 0.281 \\
\hline & 22.9 & $0.797 \pm 0.01$ & $66.4 \pm 3$ & 0.281 \\
\hline & 25.0 & $0.948 \pm 0.01$ & $53.9 \pm 3$ & 0.281 \\
\hline & 25.8 & $1.010 \pm 0.01$ & $50.5 \pm 3$ & 0.281 \\
\hline \multirow[t]{4}{*}{ American blend type } & 21.3 & $0.652 \pm 0.01$ & $94.7 \pm 3$ & 0.264 \\
\hline & 22.8 & $0.747 \pm 0.01$ & $79.8 \pm 3$ & 0.264 \\
\hline & 25.0 & $0.893 \pm 0.01$ & $66.2 \pm 3$ & 0.264 \\
\hline & 25.8 & $0.952 \pm 0.01$ & $61.9 \pm 3$ & 0.264 \\
\hline
\end{tabular}

Table 1. Physical variables of tobacco columns (65 $\mathrm{mm}$ length).

\footnotetext{
"Excluding the weight of cigarette paper.
} 
DeBardeleben et al. reported a reduction of tar, nicotine and carbon monoxide delivery with decreasing circumference (3). However, there has been no report on the quantitative relationship between the change in circumference and the amounts of components in the mainstream smoke, by considering smoke generation and its behaviour after generation.

In the present experiment, the amounts of tar and nicotine in the mainstream smoke of cigarettes of different circumferences but with a constant packing density were estimated from the weight of tobacco column and nicotine content per unit length, as a result of the establishment of the proportional nature of the relationship between the weight loss during puffs and the delivery of these components.

\section{MATERIALS AND METHODS}

\section{Cigarette Samples}

Two types of tobacco columns, Virginia and American blends, were prepared. The cut width of the shred was $0.8 \mathrm{~mm}$, and ordinary cigarette paper (permeability : about $10 \mathrm{ml} / \mathrm{cm}^{2} / \mathrm{min} / 100 \mathrm{~mm}$ w.g.) was used. After conditioning at $22^{\circ} \mathrm{C}$ and $60 \%$ relative humidity, the columns were selected at the weight and pressure drop shown in Table 1 , so as to keep the packing density of the columns contant. Acetate filters $(20 \mathrm{~mm}$ length), as described in Table 2, were attached to the columns with adhesive cellophane tape so that the retention of tar and nicotine by the filter could be measured directly (4).

\section{Determination of Tar and Nicotine Content}

The cigarettes were smoked to a $30 \mathrm{~mm}$ butt length on a smoking machine (Filtrona, Model 302) under standard smoking conditions. The total particulate matter (TPM) was trapped on a Cambridge filter pad and measured gravimetrically. The water content was measured by gas chromatographic analysis of the $n$-propanol extract of TPM, and the nicotine content was determined by spectrophotometric analysis of the steam distillate of the $n$-propanol extract. The amounts of tar on the Cambridge filter pad and cigarette filter were obtained by subtracting the weight of water from the weight of TPM.

Table 2.

Physical variables of the acetate filter tips (2 cm length).

\begin{tabular}{c|c|c|c}
\hline $\begin{array}{c}\text { Circumference } \\
(\mathrm{mm})\end{array}$ & $\begin{array}{c}\text { Weight } \\
(\mathrm{mg})\end{array}$ & $\begin{array}{c}\text { Pressure drop } \\
\text { (mm w.g.) }\end{array}$ & $\begin{array}{c}\text { Fractional } \\
\text { volume }\end{array}$ \\
\hline 20.65 & 93.7 & $66 \pm 2$ & 0.087 \\
22.65 & 117.6 & $66 \pm 2$ & 0.093 \\
24.67 & 149.2 & $66 \pm 2$ & 0.101 \\
25.67 & 164.0 & $66 \pm 2$ & 0.103 \\
\hline
\end{tabular}

Measurement of Weight Loss during a Puff

The amount of cigarette burned during a puff was measured as weight loss. The weight loss during a puff $\left(\mathbb{W}_{p}\right)$ was obtained by measuring the difference in the weights of the shortened tobacco columns just before and just after the puffing, as reported previously (2).

\section{Estimation of Filtration Coefficients of the Tobacco Column for Tar and Nicotine}

Generally, the following equation can be applied, where $C_{\text {out }}$ and $C_{i n}$ are the amounts of smoke components at the exit and inlet of the tobacco column respectively, $l_{t}$ is the length of the column and $\mu_{f}$ is defined to be the filtration coefficient:

$$
\mathrm{C}_{\text {out }}=\mathrm{C}_{\text {in }} \mathrm{e}^{-\mu_{\mathrm{t}} \mathrm{l}_{\mathrm{t}}} \text {. }
$$

In the present experiment, tobacco columns shortened to various lengths were smoked at a constant puff count (5). After the fourth and final puff, the burning cone was extinguished by pressing the cone with tweezers, and the butt length was measured with a vernier caliper. Having established equation 1 from the linear relationship between the logarithmic values of the amount of tar and nicotine in the mainstream smoke and the butt length, the filtration coefficient of the tobacco column for these components was obtained as the gradient of the regression line.

\section{Total Deliveries of Tar and Nicotine}

The total deliveries of tar $\left(T_{t}\right)$ and nicotine $\left(N_{t}\right)$, which correspond to the amount generated during puffs, were given by the following equations:

$$
\begin{aligned}
& T_{s}=T_{t} e^{-\mu_{l_{t}} e_{t}} e^{-\mu_{f} l_{f}}, \\
& N_{s}=N_{t} e^{-\mu_{t} l_{t}} e^{-\mu_{f} l_{f}},
\end{aligned}
$$

where $T_{s}$ and $N_{s}$ are the amounts of tar and nicotine in the mainstream smoke, $\mu_{r}$ and $\mu_{f}$ are filtration coefficients of the tobacco column and filter, and $l_{r}$ and $l_{f}$ are the lengths of the tobacco column and filter, respectively. In this study, $1_{r}$ was $1 \mathrm{~cm}$ and $l_{\mathrm{f}} 2 \mathrm{~cm}$. The filtration coefficient $\mu_{t}$ was obtained as described above, and $\mu_{\mathrm{f}}$ by the direct method (4).

\section{RESULTS AND DISCUSSION}

\section{Weight Loss during Puffs}

As shown in Table 3, the puff count $\mathrm{n}$ decreased with decreasing circumference, and the ratio of $n$ to $2 \pi r$ was nearly constant. This proportional relationship between 
Table 3.

Relationship between circumference and puff count.

$\left.\begin{array}{c|c|c|r}\hline \begin{array}{c}\text { Circumference } \\ (2 \pi r) \\ (\mathrm{mm})\end{array} & \text { Puff count } & \mathrm{n} /(2 \pi) & \text { Statistics* } \\ \hline \multicolumn{2}{l|}{\text { Virginia blend type: }} & & \\ 21.1 & 8.5 & 0.403 \\ 22.9 & 9.6 & 0.419 \\ 25.0 & 10.0 & 0.400 \\ 25.8 & 10.9 & 0.422\end{array}\right\} \quad \begin{array}{r}\text { C. } \mathrm{X}: 0.411 \\ \end{array}$

American blend type:

$\left.\begin{array}{lll}21.3 & 7.4 & 0.347 \\ 22.8 & 7.7 & 0.338 \\ 25.0 & 8.0 & 0.320 \\ 25.8 & 9.0 & 0.349\end{array}\right\} \begin{array}{r}\mathrm{X}: 0.339 \\ \text { C. } V .: 3.8 \%\end{array}$

* $\overline{\mathrm{x}}:$ mean

C. V. : coefficient of variation

Table 4.

Relationship between circumference and weight loss during a puff.

\begin{tabular}{|c|c|c|c|c|c|}
\hline & \multirow{2}{*}{$\begin{array}{c}\text { Circumference } \\
(2 \pi r) \\
(\mathrm{mm})\end{array}$} & \multicolumn{2}{|c|}{$\begin{array}{c}\text { Weight loss } \\
\text { during a puff }\left(W_{p}\right)\end{array}$} & \multicolumn{2}{|c|}{$W_{p} /(2 \pi r)$} \\
\hline & & $\begin{array}{c}X \\
\text { (mg) }\end{array}$ & $\begin{array}{c}\text { Coefficient of variation } \\
\text { (C. V.) } \\
\text { (\%) }\end{array}$ & $(\mathrm{mg} / \mathrm{mm})$ & Statistics \\
\hline \multirow[t]{4}{*}{ Virginia blend type } & 21.1 & 20.97 & 4.9 & 0.994 & \\
\hline & 22.9 & 22.66 & 5.0 & 0.990 & $\mathrm{x}: 1.002$ \\
\hline & 25.0 & 25.48 & 4.0 & 1.019 & c. V.: $1.3 \%$ \\
\hline & 25.8 & 25.89 & 5.0 & 1.003 & \\
\hline \multirow[t]{4}{*}{ American blend type } & 21.3 & 23.36 & 3.7 & 1.097 & \\
\hline & 22.8 & 25.19 & 4.3 & 1.105 & $\mathrm{x}: 1.106$ \\
\hline & 25.0 & 27.71 & 6.9 & 1.108 & C. V.: $0.7 \%$ \\
\hline & 25.8 & 28.71 & 4.7 & 1.113 & \\
\hline
\end{tabular}

Table 5.

Ratlo of welght consumed during puff's to total weight.

\begin{tabular}{|c|c|c|c|c|c|c|}
\hline & $\begin{array}{c}\text { Circumference } \\
(2 \pi r) \\
(\mathrm{mm})\end{array}$ & Puff count & $\begin{array}{c}\text { Weight consumed } \\
\text { during puffs: } \\
\mathrm{nW}_{\mathrm{p}} /\left(1-\mathrm{A}^{*} / 100\right) \\
\text { (mg) }\end{array}$ & $\begin{array}{c}\text { Weight of } 55 \mathrm{~mm} \\
\text { tobacco rod: } \\
\mathrm{W}_{0} \\
(\mathrm{mg})\end{array}$ & $n W_{p} /\left((1-A / 100) / W_{0}\right)$ & Statistics ${ }^{* *}$ \\
\hline \multirow[t]{4}{*}{ Virginia blend type } & 21.1 & 8.5 & 206.1 & 577.1 & 0.357 & \\
\hline & 22.9 & 9.6 & 251.5 & 674.4 & 0.373 & $\mathrm{x}: 0.370$ \\
\hline & 25.0 & 10.0 & 294.6 & 802.2 & 0.367 & C. V.: $2.7 \%$ \\
\hline & 25.8 & 10.9 & 326.3 & 854.6 & 0.381 & \\
\hline \multirow{4}{*}{$\begin{array}{l}\text { American } \\
\text { blend type }\end{array}$} & 21.3 & 7.4 & 204.5 & 551.7 & 0.371 & \\
\hline & 22.8 & 7.7 & 229.5 & 674.4 & 0.340 & X: 0.359 \\
\hline & 25.0 & 8.0 & 262.3 & 755.6 & 0.347 & c. V.: $5.3 \%$ \\
\hline & 25.8 & 9.0 & 305.8 & 805.5 & 0.379 & \\
\hline
\end{tabular}

* Ash content of Virginia blend type: $13.52 \%$,

ash content of American blend type: $15.49 \%$.

The ash content was obtained from the weight of ash formed by static burning. 
$\mathrm{n}$ and $\mathrm{r}$ at a constant packing density agrees with the findings obtained by Okada et al. who measured the length burned during and between puffs (1). Table 4 shows the relationship between circumference and weight loss during a puff $\left(W_{p}\right)$. $W_{p}$ decreased with decreasing circumference, and at the same circumference the value for the American blend type was higher than that for the Virginia blend type. The ratio of $W_{p}$ to $2 \pi r$ was almost constant, because the coefficient of variation was very small. The data in Tables 3 and 4 yield the following equations:

$$
\begin{gathered}
n \propto r \\
W_{p} \propto r
\end{gathered}
$$

It is thought that, during a puff, the tobacco in a cigarette burns more rapidly around the periphery than in the center due to the large influx of air just behind the paper burn line where the draw resistance is lowest $(6$, $7)$. In addition, the effect of the periphery on mainstream smoke has been measured using carbon-14 (8). The proportional relationship between $W_{p}$ and $r$, as shown in Table 4, can be explained by the above-mentioned finding, namely that the peripheral region of a cigarette burns mainly during puffs.

It is natural that $W_{p}$ is influenced by the amount of air inflow through the burning cone during a puff. As the permeability of the cigarette paper used in this study was very low, the air inflow through the burning cone during a puff was considered to be almost constant as burning progressed. Therefore, the total weight loss during puffs can be expressed as $n W_{p}$, which is an important factor in the total delivery of smoke components in mainstream smoke. The amount of cigarette consumed during puffs was calculated from $\mathrm{nW}_{\mathrm{p}} /(1-$ $A / 100$ ), where $A$ is the ash content (\%) based on the actual shred weight. This value and the weight of a tobacco column of $55 \mathrm{~mm}$ ( $W_{0}$ ) which corresponds to the total weight burned, are shown in Table 5 . The ratio of $\mathrm{nW}_{\mathrm{p}} /(1-\mathrm{A} / 100)$ to $\mathrm{W}_{\mathrm{o}}$ was almost constant in both blends. This result implies that, for cigarettes of different circumferences but a constant packing density, the ratio of cigarette weight consumed between puffs to that during puffs is independent of the circumference.

\section{Total Deliveries of Tar and Nicotine during Puffs}

To obtain the filtration coefficients, the amounts of tar and nicotine in the mainstream smoke were determined using tobacco columns of different, lengths at a constant puff count (four puffs). These results are shown in Figures 1 and 2. The linear relationship between the logarithmic values of tar and nicotine in the mainstream smoke and the butt length seems to verify equation 1 . The filtration coefficients $\mu_{r}$ and $\mu_{f}$ are shown in Table 6. Both $\mu_{\mathrm{f}}$ and $\mu_{\mathrm{f}}$, for tar and nicotine respectively, decreased with decreasing circumference. This is speculated to be due to an increase in the velocity of air passing through the cigarette during a puff as a result of the decrease in circumference.

It has been reported that, for tobacco columns as well as filters $\mathbf{2 5} \mathrm{mm}$ in circumference, the filtration coefficient for nicotine is lower than that for tar $(5,9)$. In this work, a similar tendency was observed in tobacco columns of different circumferences. The total deliveries of $\operatorname{tar}\left(\mathrm{T}_{\mathrm{t}}\right)$ and nicotine $\left(\mathrm{N}_{\mathrm{t}}\right)$ as well as those proportions attributable to the tobacco column, the filter and the mainstream smoke, were obtained from equations 1, 2 and 3. These results are shown in Tables 7 and 8 . The total deliveries of tar and nicotine decreased with decreasing circumference. However, their proportion $(\%)$ in the mainstream smoke increased with decreasing circumference as a result of a decrease in their retention by the tobacco column and filter.

\section{Estimation of Tar and Nicotine in Mainstream Smoke}

Table 9 shows the ratio of total delivery $\left(T_{t}\right.$ and $\left.N_{t}\right)$ to the weight loss during puffs $\left(\mathrm{nW}_{\mathrm{p}}\right)$. The ratios for tar and nicotine were almost constant because the coefficients of variation were very small. This yields the following equations:

$$
\begin{aligned}
& \mathrm{T}_{\mathrm{t}} \propto \mathrm{nW}_{\mathrm{p}}, \\
& \mathrm{N}_{\mathrm{r}} \propto \mathrm{nW}_{\mathrm{P}} .
\end{aligned}
$$

From equations 4, 5 and 6 , and 4, 5 and 7, the following equations were derived:

$$
\begin{aligned}
& \mathrm{T}_{\mathrm{t}} \propto \mathrm{r}^{2}, \\
& \mathrm{~N}_{\mathrm{t}} \propto \mathrm{r}^{2} .
\end{aligned}
$$

Table 6.

Filtration coefficlent of tobacco column and filter.

\begin{tabular}{c|c|c|c|c}
\hline \multirow{2}{*}{$\begin{array}{c}\text { Circum- } \\
\text { ference }\end{array}$} & \multicolumn{2}{|c|}{ Tobacco column $\left(\mu_{4}\right)$} & \multicolumn{2}{c}{ Filter $\left(\mu_{4}\right)$} \\
\cline { 2 - 5 }$(\mathrm{mm})$ & $\begin{array}{c}\text { tar } \\
\left(\mathrm{cm}^{-1}\right)\end{array}$ & $\begin{array}{c}\text { nicotine } \\
\left(\mathrm{cm}^{-1}\right)\end{array}$ & $\begin{array}{c}\text { tar } \\
\left(\mathrm{cm}^{-1}\right)\end{array}$ & $\begin{array}{c}\text { nicotine } \\
\left(\mathrm{cm}^{-1}\right)\end{array}$ \\
\hline \multicolumn{2}{c}{ Virginia blend type: } & & & \\
21.1 & 0.082 & 0.049 & 0.203 & 0.149 \\
22.9 & 0.085 & 0.054 & 0.232 & 0.169 \\
25.0 & 0.097 & 0.070 & 0.262 & 0.199 \\
25.8 & 0.108 & 0.073 & 0.265 & 0.209 \\
& & & & \\
American blend type: & & & \\
21.3 & 0.090 & 0.060 & 0.188 & 0.155 \\
22.8 & 0.097 & 0.074 & 0.219 & 0.182 \\
25.0 & 0.107 & 0.085 & 0.242 & 0.228 \\
25.8 & 0.116 & 0.095 & 0.260 & 0.234 \\
\hline
\end{tabular}


Figure 1.

Tar delivery (logarithmic scale) in the mainstream smoke v8. butt length of non-filter tobacco column.
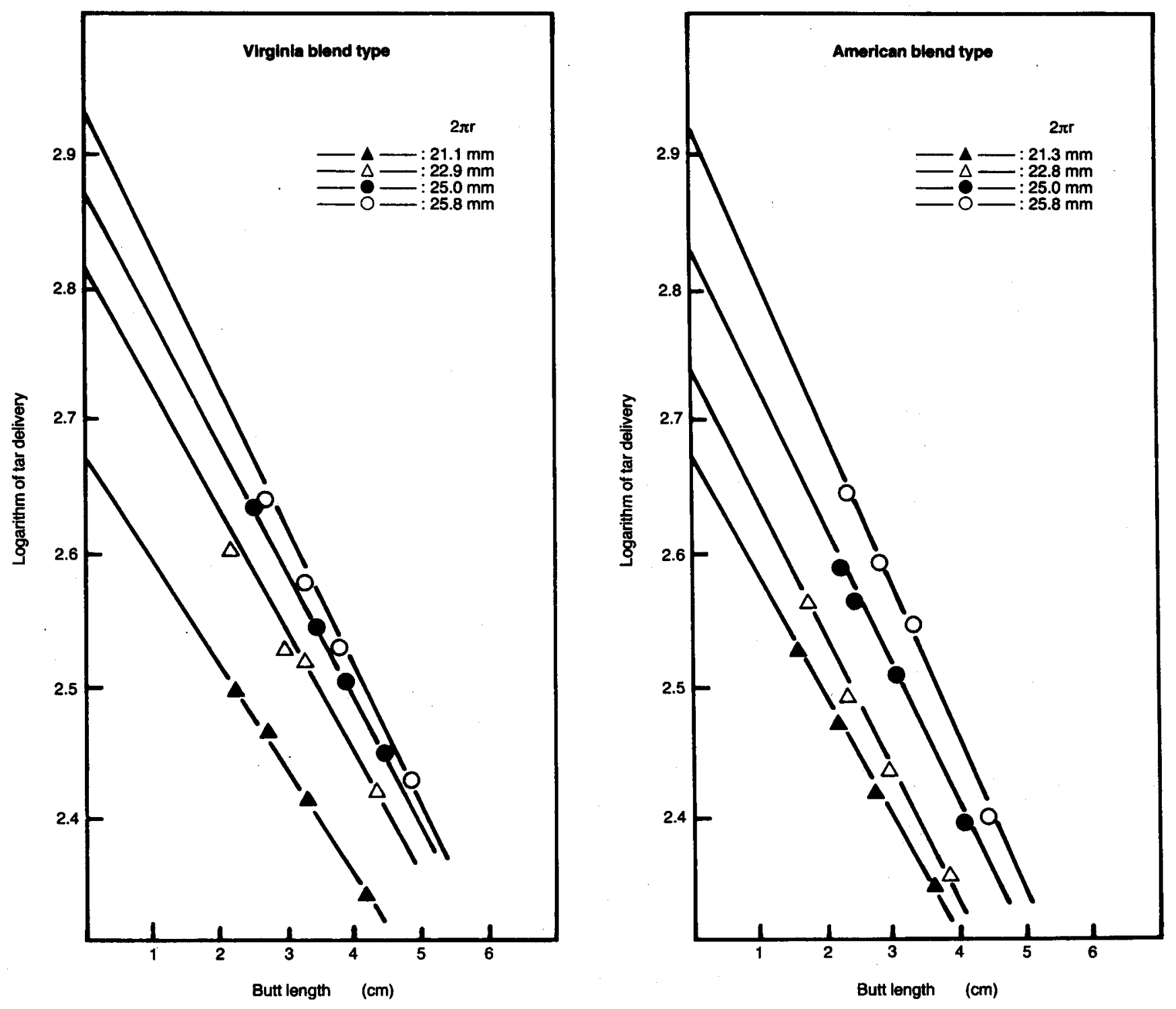
Figure 2.

Nicotine dellvery (logarithmic scale) in the mainstream smoke vs. butt length of non-fllter tobacco column.
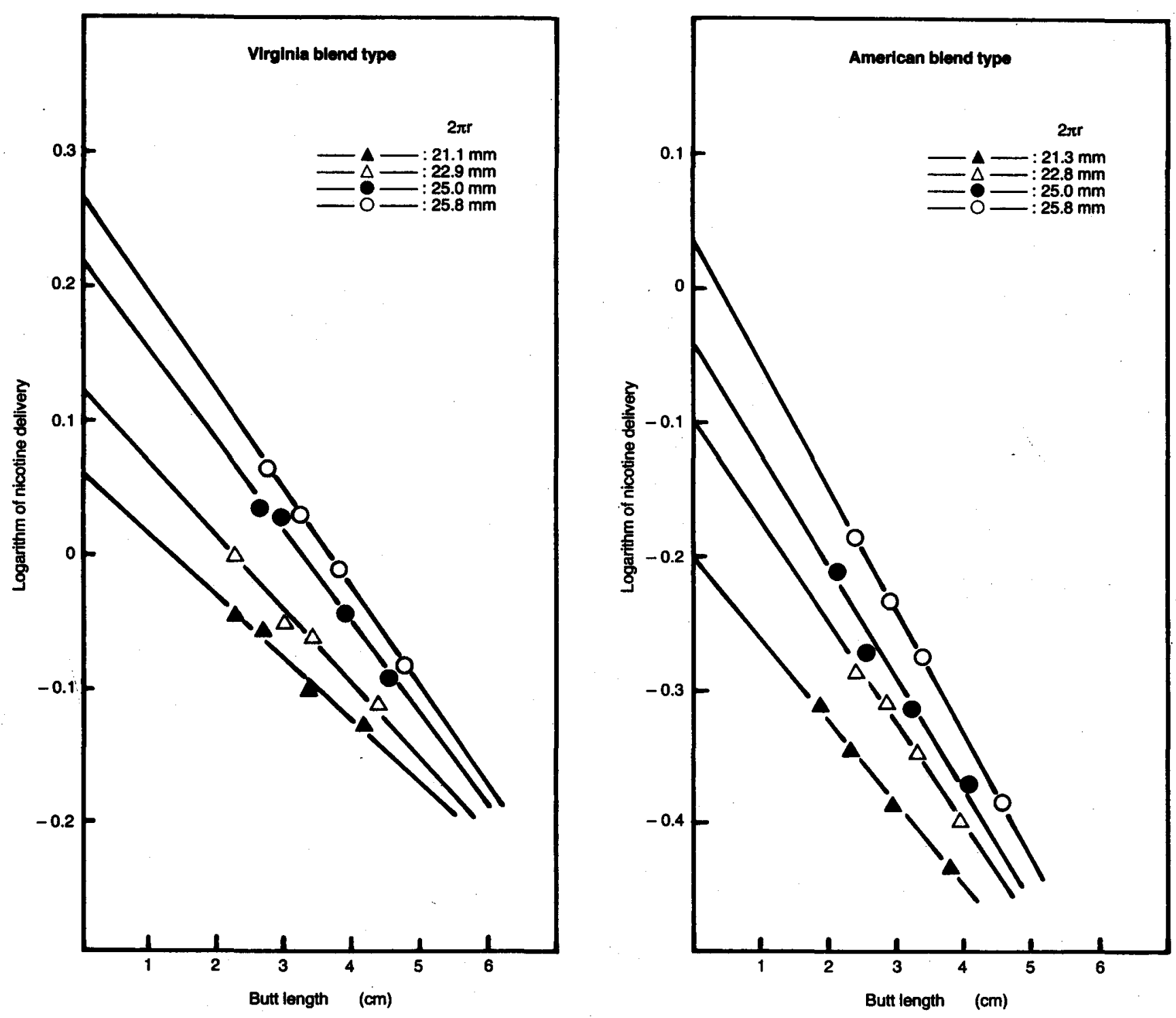
Table 7.

Distribution of tar among the tobacco column, filter and mainstream smoke.*

\begin{tabular}{|c|c|c|c|c|c|c|c|c|c|}
\hline & \multirow{2}{*}{$\begin{array}{c}\text { Circum- } \\
\text { ference } \\
\text { (mm) }\end{array}$} & \multicolumn{2}{|c|}{ Tobacco column $(1 \mathrm{~cm})$} & \multicolumn{2}{|c|}{ Filter $(2 \mathrm{~cm})$} & \multicolumn{2}{|c|}{ Mainstream smoke } & \multicolumn{2}{|c|}{ Total delivery } \\
\hline & & (mg) & $(\%)$ & $(\mathrm{mg})$ & $(\%)$ & (mg) & $(\%)$ & $(\mathbf{m g})$ & $(\%)$ \\
\hline \multirow{4}{*}{$\begin{array}{l}\text { Virginia } \\
\text { blend type }\end{array}$} & 21.1 & 2.64 & 8.1 & 9.99 & 30.6 & 20.05 & 61.3 & 32.68 & 100 \\
\hline & 22.9 & 3.32 & 8.7 & 12.94 & 33.9 & 21.90 & 57.4 & 38.16 & 100 \\
\hline & 25.0 & 4.26 & 9.2 & 17.11 & 37.1 & 24.81 & 53.7 & 46.18 & 100 \\
\hline & 25.8 & 4.98 & 10.3 & 17.79 & 36.9 & 25.47 & 52.8 & 48.24 & 100 \\
\hline \multirow{4}{*}{$\begin{array}{l}\text { American } \\
\text { blend type }\end{array}$} & 21.3 & 2.19 & 8.5 & 7.45 & 28.8 & 16.26 & 62.7 & 25.90 & 100 \\
\hline & 22.8 & 2.64 & 9.2 & 9.31 & 32.3 & 16.88 & 58.5 & 28.83 & 100 \\
\hline & 25.0 & 3.52 & 10.0 & 12.07 & 34.5 & 19.44 & 55.5 & 35.03 & 100 \\
\hline & 25.8 & 4.23 & 11.0 & 13.84 & 36.0 & 20.33 & 53.0 & 38.40 & 100 \\
\hline
\end{tabular}

* Length of cigarette smoked: $55 \mathrm{~mm}$.

Table 8.

The distribution of nicotine generated among the tobacco column, filter and the mainstream smoke.*

\begin{tabular}{|c|c|c|c|c|c|c|c|c|c|}
\hline & \multirow{2}{*}{$\begin{array}{c}\text { Circum- } \\
\text { ference } \\
\text { (mm) }\end{array}$} & \multicolumn{2}{|c|}{ Tobacco column $(1 \mathrm{~cm})$} & \multicolumn{2}{|c|}{ Filter $(2 \mathrm{~cm})$} & \multicolumn{2}{|c|}{ Mainstream smoke } & \multicolumn{2}{|c|}{ Total delivery } \\
\hline & & (mg) & $(\%)$ & (mg) & $(\%)$ & (mg) & $(\%)$ & (mg) & $(\%)$ \\
\hline \multirow{4}{*}{$\begin{array}{l}\text { Virginia } \\
\text { blend type }\end{array}$} & 21.1 & 0.11 & 4.7 & 0.57 & 24.6 & 1.64 & 70.7 & 2.32 & 100 \\
\hline & 22.9 & 0.14 & 5.1 & 0.75 & 27.3 & 1.86 & 67.6 & 2.75 & 100 \\
\hline & 25.0 & 0.22 & 6.8 & 0.99 & 30.6 & 2.03 & 62.6 & 3.24 & 100 \\
\hline & 25.8 & 0.25 & 6.9 & 1.15 & 31.9 & 2.21 & 61.2 & 3.61 & 100 \\
\hline \multirow{4}{*}{$\begin{array}{l}\text { American } \\
\text { blend type }\end{array}$} & 21.3 & 0.09 & 6.1 & 0.37 & 25.0 & 1.02 & 68.9 & 1.48 & 100 \\
\hline & 22.8 & 0.12 & 7.4 & 0.46 & 28.2 & 1.05 & 64.4 & 1.63 & 100 \\
\hline & 25.0 & 0.17 & 8.5 & 0.67 & 33.5 & 1.16 & 58.0 & 2.00 & 100 \\
\hline & 25.8 & 0.20 & 9.3 & 0.73 & 34.0 & 1.22 & 56.7 & 2.15 & 100 \\
\hline
\end{tabular}

" Length of clgarette smoked: $55 \mathrm{~mm}$.

Table 9.

The relation of total dellvery of tar and nicotine to the weight loss during puffe.*

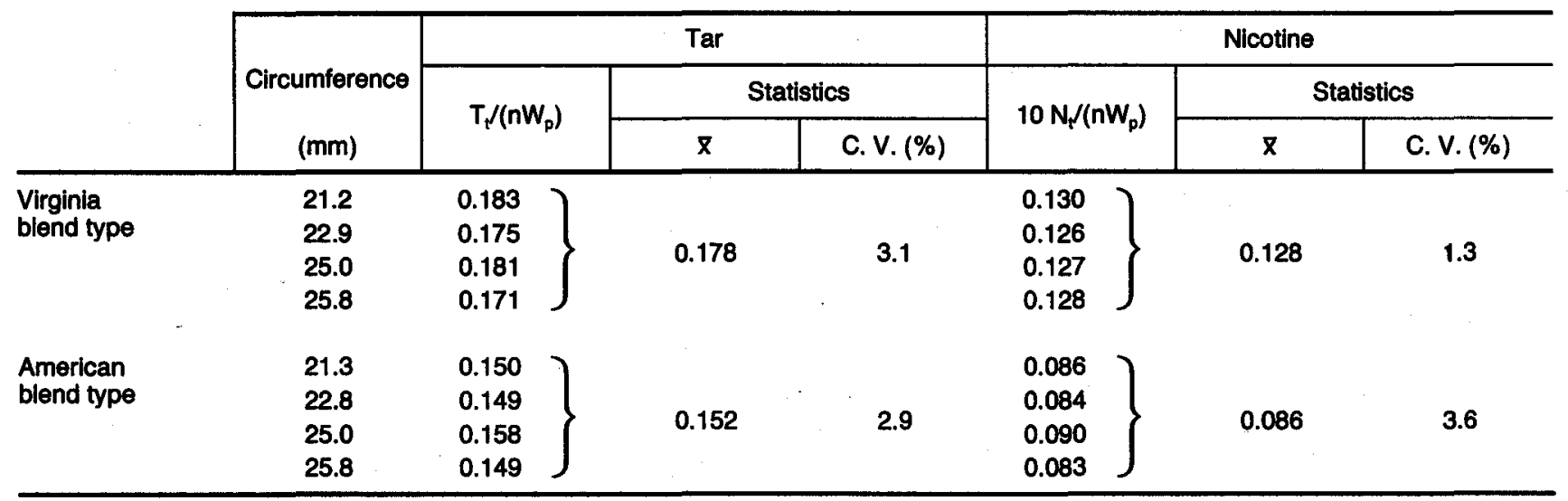

\footnotetext{
" $T_{t}=$ total dellvery of tar shown in Table 7.

$N_{1}=$ total dellvery of nicotine shown in Table 8.

$n W_{p}=$ weight loss during putfs.
} 
Figure 3.

Total dellvery of tar vs. welght per unit length of tobacco columns of various circumferences.

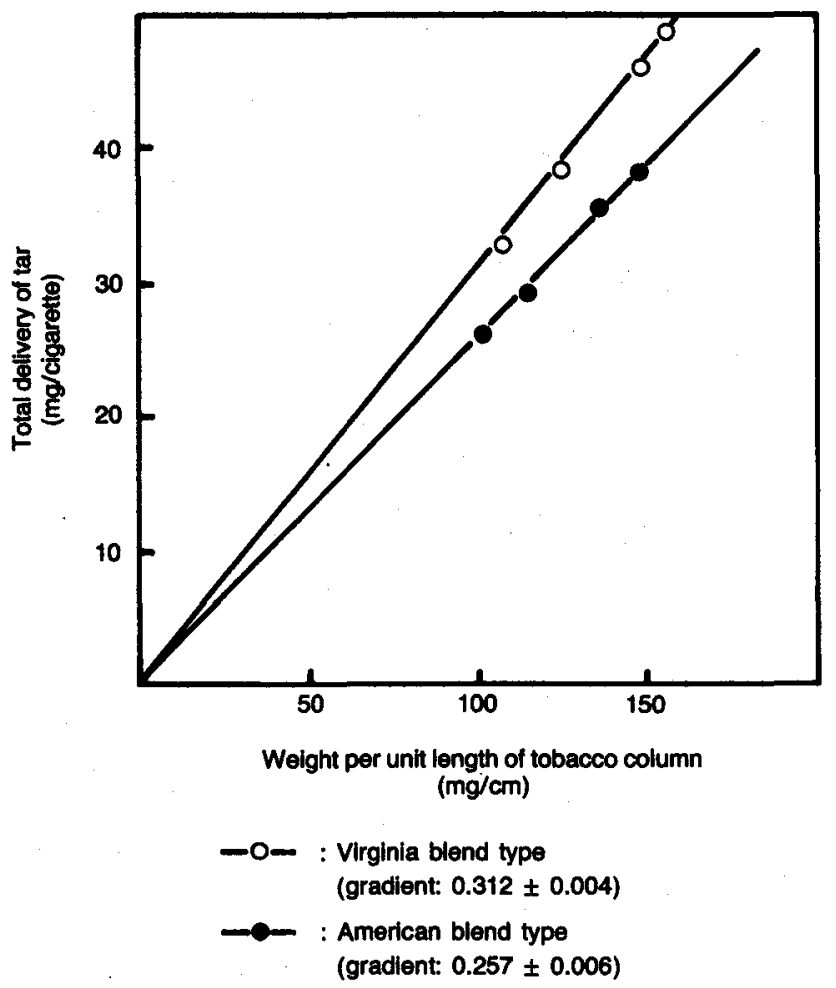

Using the relationship $W=\pi r^{2} \mathrm{QL}$, equations 8 and 9 were converted into the equations 10 and 11 , under the condition that the packing density (Q) remains constant:

$$
\begin{aligned}
& \mathrm{T}_{\mathrm{t}} \propto \mathrm{W} / \mathrm{L}, \\
& \mathrm{N}_{\mathrm{t}} \propto \mathrm{W} / \mathrm{L},
\end{aligned}
$$

where $W$ and $L$ are the weight and length respectively of the tobacco column. Furthermore, for the same blend of tobacco, the following equation was derived from equation 11 :

$$
N_{t} \propto(W / L)\left(n_{s} / 100\right)
$$

where $W / L$ is the weight per unit length of the tobacco column and $n_{s}$ is the nicotine content $(\%)$ based on the actual weight. Consequently, (W/L) $\left(n_{s} / 100\right)$ corresponds to the amount of nicotine per unit length of the tobacco column. Figures 3 and 4 show the relationships between $T_{t}$ and $N_{t}$, as shown in Tables 7 and 8 , and the weight and nicotine content per unit length of the tobacco column. All the points fell on a straight line passing through the origin, showing a very high linearity. These experimental observations indicate that equations 10 and 12 have been sufficiently verified.

In order to obtain estimates of the amounts of tar and
Figure 4.

Total dellvery of nicotine vs. nicotine per unit length of tobacco columns of various clrcumferences.

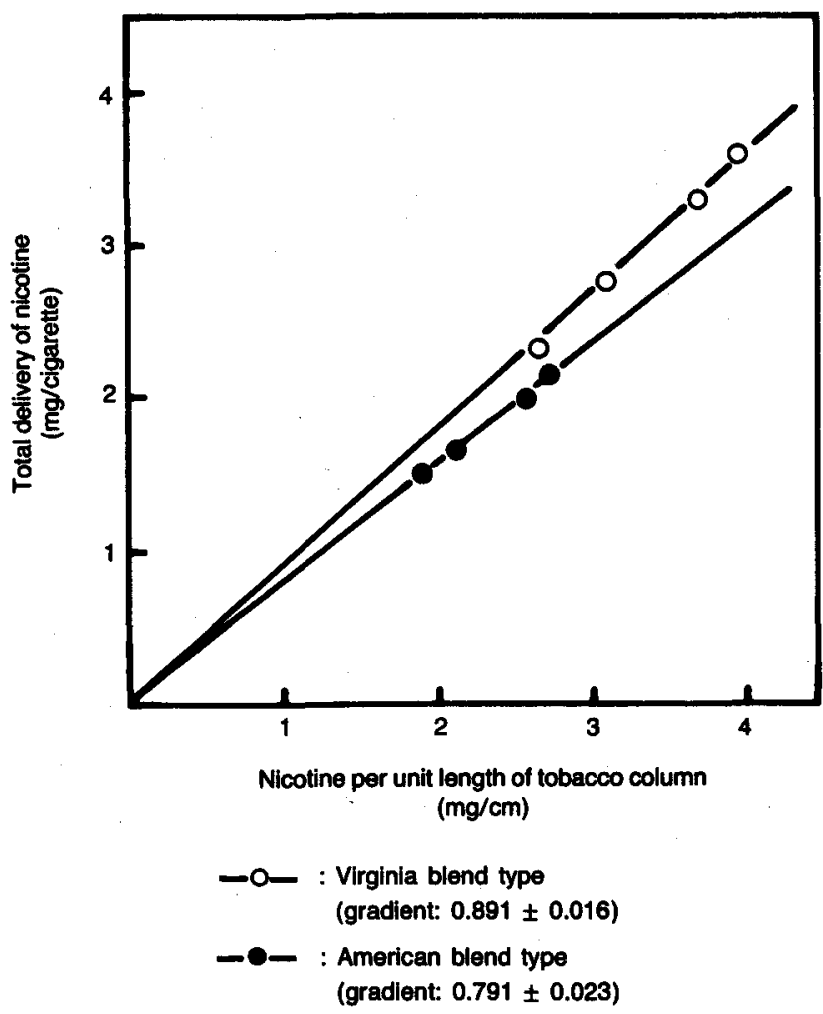

nicotine in mainstream smoke, equations 2 and 3 were substituted in equations 10 and 12 respectively, yielding the following:

$$
\begin{aligned}
& \mathrm{T}_{s}=\mathrm{K}_{\mathrm{t}}(\mathrm{W} / \mathrm{L}) \mathrm{e}^{-\mu_{\mathrm{t}} \mathrm{I}_{\mathrm{t}}} \mathrm{e}^{-\mu_{\mathrm{f}} \mathrm{f}_{\mathrm{f}}}, \\
& \mathrm{N}_{\mathrm{s}}=\mathrm{K}_{\mathrm{n}}(\mathrm{W} / \mathrm{L})\left(\mathrm{n}_{\mathrm{s}} / 100\right) \mathrm{e}^{-\mu_{\mathrm{l}} \mathrm{I}_{\mathrm{t}}} \mathrm{e}^{-\mu_{\mathrm{f}} \mathrm{f}_{\mathrm{f}}} .
\end{aligned}
$$

The constants $\mathrm{K}_{\mathrm{t}}$ and $\mathrm{K}_{\mathrm{n}}$ are regarded as an index of the formation rate of tar and nicotine during puffs.

Furthermore, an experiment was carried out in order to determine whether or not the relationship expressed in equations 13 and 14 can be applied to cigarettes with other blends and to those with different shred cut widths. As shown in Table 10 , the values of $K_{t}$ and $K_{n}$ calculated from the observed values of $T_{3}, N_{3}, n_{s}$ and $\mathrm{W} / \mathrm{L}$ are nearly constant, independent of the circumference but dependent on the blend type and the cut width of the shred.

From these experimental observations, it can be concluded that when the amounts of tar and nicotine in mainstream smoke are known for one cigarette $25 \mathrm{~mm}$ in circumference for example, the amount of tar and nicotine in the mainstream smoke of another cigarette of the same blend and packing density but differing in circumference can easily be estimated from equations 13 and 14. 


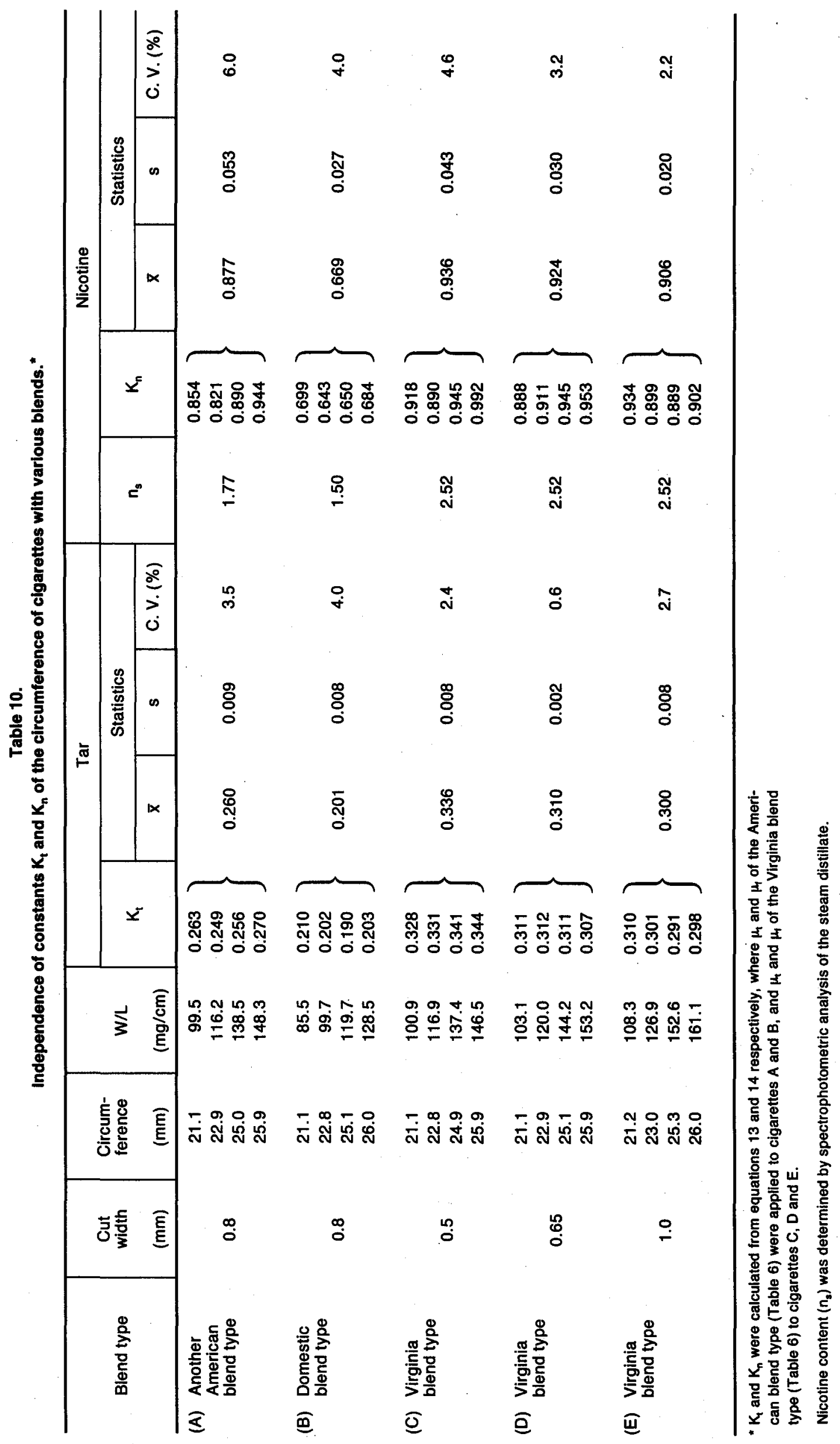




\section{REFERENCES}

1. Okada, T., K. Ohta and Y. Masuo: A study of the burning rate of cigarettes between puffs; Paper presented at the 31st 'Tobacco Chemists' Research Conference, Greensboro, North Carolina, 1977.

2. Yamamoto, T.: The effect of packing density, circumference and the kind of shreds on the weight loss during a puff and carbon oxides delivery in the mainstream smoke; Jpn, Monop. Corp. Cent. Res. Inst. Sci. Pap. 123 (1981) 1-8.

3. DeBardeleben, Marian Z., Warren E. Claflin and Walter F. Gannon: Role of cigarette physical characteristics on smoke composition; Recent Adv. Tob. Sci. 4 (1978) 85-111.

4a. Coresta Standard Method No. 10 (September 1968): Machine smoking of cigarettes, determination of crude and dry smoke condensate; Coresta Information Bulletin 1969-1, pp. 14-33.

4b. Coresta Standard Method No. 12 (September 1968): Determination of alkaloids in cigarette smoke condensates; Coresta Information Bulletin 1969-2, pp. 5-8.

4c. Coresta Standard Method No. 13 (September 1968): Determination of alkaloid retention by cigarette filters; Coresta Information Bulletin 1969-2, pp. $9-20$.
5. Byckling, E.: Untersuchung der Filterwirksamkeit des Tabakstranges bei Cigaretten verschiedener Härte in Abhängigkeit von der Abrauchlänge; Beitr. Tabakforsch. 8 (1976) 382-391.

6. Wakeham, H.: Recent trends in tobacco and tobacco smoke research; in: The chemistry of tobacco and tobacco smoke, edited by I. Schmeltz, Plenum Press, New York-London, 1972, pp. 1-20.

7. Baker, R. R.: Mechanisms of smoke formation and delivery; Recent Adv. Tob. Sci. 6 (1980) 184-224.

8. Jenkins, R. W., Jr., Roger T. Bass, Richard H. Newman and Marie K. Chavis: Cigarette smoke formation studies, V. The effects of the cigarette periphery on mainstream smoke formation; Beitr. Tabakforsch. 9 (1977) 126-130.

9. Yamamoto, T:: Butt retention for dry and wet TPM, and nicotine; Jpn. Monop. Corp. Cent. Res. Inst. Sci. Pap. 123 (1981) 125-130.

Autbors'address:

Central Research Institute, The Japan Tobacco \& Salt Public Corporation, 6-2 Umegaoka, Midori-ku, Yokohama, Kanagawa, 227, Japan. 